DOI: $10.20472 /$ IAC.2019.045.036

\author{
JORGE OMAR RAZO-DE ANDA \\ INSTITUTO POLITÉCNICO NACIONAL, Mexico \\ SALVADOR CRUZ-AKÉ \\ INSTITUTO POLITÉCNICO NACIONAL, Mexico \\ ANA CECILIA PARADA-ROJAS \\ INSTITUTO POLITÉCNICO NACIONAL, Mexico
}

\title{
THE CREDIT CYCLE AND THE FINANCIAL FRAGILITY HYPOTHESIS: AN EVOLUTIONARY POPULATION APPROACH
}

\begin{abstract}
:
Minsky's idea of triggering a financial crisis is the adoption of risky financial positions by companies and their relationship with the financial system through banks and the credit they provide. The present work seeks to provide an explanation from a microeconomic point of view through the behavior of agents and their decision making under a Theory of evolutionary games, especially population games. The great advantage of this type of games is that it allows us to obtain proportions of the different decisions that a population or subpopulation is taking and how their interaction promotes equilibrium and the dynamics towards (or around) them.

This allows us to determine the dynamics and equilibria of the credit cycle, following Minsky's idea of financial fragility. Additionally, the dynamics of the replicator allows transforming the differential equations in a Lotka-Volterra system, from which it can be concluded that both companies and banks adopt a predatory prey relationship in order to survive.
\end{abstract}

\section{Keywords:}

Capital Structure, Evolutionary Games, Behavioral Microeconomics

JEL Classification: G02, C73, G01 